\title{
Sedation in Critically III Children with Respiratory Failure
}

\author{
Nienke J. Vet ${ }^{1,2}$, Niina Kleiber ${ }^{1,3,4}$, Erwin Ista ${ }^{1,2}$, Matthijs de Hoog ${ }^{1,2}$ and \\ Saskia N. de Wildt ${ }^{1,3,5 *}$ \\ ${ }^{1}$ Intensive Care, Erasmus MC - Sophia Children's Hospital, Rotterdam, Netherlands, ${ }^{2}$ Department of Pediatrics, Erasmus \\ MC - Sophia Children's Hospital, Rotterdam, Netherlands, ${ }^{3}$ Department of Pediatric Surgery, Erasmus MC - Sophia \\ Children's Hospital, Rotterdam, Netherlands, ' ${ }^{4}$ Department of Pediatrics, CHU Sainte-Justine, Montreal, QC, Canada, \\ ${ }^{5}$ Department of Pharmacology and Toxicology, Radboud University, Nijmegen, Netherlands
}

\section{OPEN ACCESS}

Edited by:

Kanwaljeet J. S. Anand,

Stanford University, USA

Reviewed by:

Gregory B. Hammer,

Stanford University, USA

Doug F. Willson,

Children's Hospital of Richmond at VCU, USA

${ }^{*}$ Correspondence: Saskia N. de Wildt s.dewildt@erasmusmc.nl

Specialty section: This article was submitted to Pediatric Critical Care, a section of the journal Frontiers in Pediatrics

Received: 28 February 2016 Accepted: 09 August 2016 Published: 24 August 2016

Citation:

Vet NJ, Kleiber N, Ista E, de Hoog M and de Wildt SN (2016) Sedation in Critically III Children with Respiratory

Failure.

Front. Pediatr. 4:89. doi: 10.3389/fped.2016.00089
This article discusses the rationale of sedation in respiratory failure, sedation goals, how to assess the need for sedation as well as effectiveness of interventions in critically ill children, with validated observational sedation scales. The drugs and non-pharmacological approaches used for optimal sedation in ventilated children are reviewed, and specifically the rationale for drug selection, including short- and long-term efficacy and safety aspects of the selected drugs. The specific pharmacokinetic and pharmacodynamic aspects of sedative drugs in the critically ill child and consequences for dosing are presented. Furthermore, we discuss different sedation strategies and their adverse events, such as iatrogenic withdrawal syndrome and delirium. These principles can guide clinicians in the choice of sedative drugs in pediatric respiratory failure.

Keywords: sedation, PICU, critically ill child, respiratory failure, pharmacokinetics, pharmacodynamics

\section{INTRODUCTION}

Critically ill children who are mechanically ventilated often require sedative and/or analgesic drugs to diminish anxiety or pain and ensure comfort. Moreover, adequate sedation facilitates synchronization with mechanical ventilation and enables invasive procedures to be performed. Adequate sedation has been described as the level of sedation at which patients are asleep but easily arousable (1). In pediatric intensive care unit (PICU) practice, this means that a child is conscious, breathes in synergy with the ventilator, and is tolerant of or compliant with other therapeutic procedures. However, the optimal level of sedation varies for each patient, depending on the type and severity of underlying disease and the need for certain therapeutic, invasive procedures.

To achieve the optimal level of sedation in individual patients, doses of sedatives are preferably titrated to effect based on observational sedation scales validated for the population in question. Nonetheless, it can be difficult to reach optimal sedation because of variability in plasma drug levels and response as well as in the patient's clinical state. Both under- and oversedation are undesirable, as these conditions may adversely affect patient outcomes. Oversedation delays recovery, as greater sedatives consumption is associated with longer duration of ventilation as well as extubation failure (2). Part of this effect may be due to muscle weakness consequent to immobility (3). Oversedation also induces tolerance and withdrawal syndrome $(4,5)$. Undersedation, on the other hand, may cause distress and adverse events such as unintentional extubation or displacement of catheters, may lead to adverse memories (posttraumatic-stress syndrome) and increased need for nursing requirements. All this may lead to a longer PICU stay.

This article addresses how to assess the need for sedation, including relevant sedation scales, pharmacokinetic (PK) and pharmacodynamic (PD) considerations of analgosedative drugs, sedation strategies, and long-term adverse effects of sedation, to guide clinicians to optimal sedation practice 
in pediatric respiratory failure. Moreover, we aim to elucidate the information gaps in current knowledge and propose future research directions.

\section{SEDATION ASSESSMENT}

In order to provide adequate sedation, the level of sedation in critically ill children should be regularly assessed and documented. Furthermore, sedation assessment is needed to both determine the efficacy of sedatives and related interventions and to facilitate inter-institutional comparisons. Thus, the use of formal sedation assessment is recommended using a validated sedation scoring scale. Several behavioral assessment tools are described. The Ramsay and the Richmond Agitation Sedation Scale (RASS) are frequently used in critically ill children, but are only validated for adult ICU patients (6-8). The COMFORT scale $(9,10)$, the COMFORT behavior scale $(11,12)$, and the State Behavioral Scale (SBS) (13) are validated scores for PICU patients. The characteristics and psychometric properties of these scales are presented in Table 1.

The COMFORT scale was originally described in and validated for measuring discomfort in ventilated pediatric patients. This observational scale consists of two physiological items - heart rate and arterial blood pressure - and six behavioral items alertness, calmness/agitation, respiratory response, physical movement, muscle tension, and facial tension. Because the physiologic variables are affected by inotropic and other drugs often used in pediatric intensive care, it was questioned whether their use contributes to the overall assessment of sedation in the individual patient. Therefore, the COMFORT scale was adapted in the COMFORT behavior scale, which does not include the two physiological items. Many psychometric properties of this scale have been tested (14-16). As well-sedated children do not always show unambiguous behavior, it was more realistic to define score ranges rather than cutoff points. Score range 6-10 was defined as oversedation; score range $23-30$ as undersedation. Score range 11-22 was defined as a gray area in which a second assessment, for example the Nurse Interpretation of Sedation Score (NISS), is recommended for clinical purposes $(12,17)$.

The SBS appraises seven behavioral dimensions; "Respiratory drive/response to ventilation," "Coughing," "Best response to stimulation," "Attentiveness to care provider," "Tolerance to care," "Consolability," and "Movement after consoled." The score range from -3 to +3 and a score of 0 describes a patient who is alert and calm. Psychometric properties of this scale are good.

\section{GENERAL CONSIDERATIONS OF PHARMACOKINETICS AND PHARMACODYNAMICS IN CRITICALLY ILL CHILDREN}

The pharmacokinetic (PK) properties of a drug include the processes of absorption, distribution, metabolism, and excretion, while the pharmacodynamic (PD) properties comprise the actual responses to the administered drug and therefore may represent both efficacy and safety. In addition to the age-related variation in PK, critical illness and its treatment modalities impact PK and PD. These factors are summarized in Figure 1. Intrinsic factors related to the patient's clinical condition include shifts in body fluid (altering volume of distribution), inflammation (altering drug transport and metabolism, clearance), and liver, renal, and

\section{TABLE 1 | Characteristics of the COMFORT (behavior) scale and the State Behavior Scale.} measured (age)
Instrument Parameter Population Exclusion criteria Observation items

\begin{tabular}{lll}
\hline COMFORT Distress & 37 & \\
scale & & (newborn to \\
$(9,10)$ & & 17 years)
\end{tabular}

COMFORT

behavior

scale (12)

Distress/ sedation

78 (0-16 years)

Children with severe mental retardation, children with severe hypotonia, and patients receiving neuromuscular blockade

State

Behavior

Scale (13)
Seriously compromised neurological Heart rate, mean arterial

Recent multiple trauma, Altered muscle ton or contractures, severe acute pain respiratory response, expression

$\begin{array}{ll}\text { Sedation/ } & 91 \text { ( } 6 \text { weeks } \\ \text { agitation } & \text { to } 6 \text { years) } \\ \text { level } & \end{array}$

Patients receiving neuromuscular blockade, postoperative patients, patients assessed to be in pain, unstable patients, patients at risk for opioid withdrawal
Heart rate, mean arterial
pressure, alertness, calmness, movement, muscle tone, facial

\section{Alertness}

Calmness/agitation

Respiratory response or crying

Physical movement

Muscle tone

Facial tension

Respiratory drive, coughing, best response to stimuli, attentiveness to care provider, tolerance to care, consolability, movement after consoled

\begin{tabular}{|c|c|c|c|}
\hline \multirow{2}{*}{$\begin{array}{l}\text { Score } \\
\text { range }\end{array}$} & \multicolumn{2}{|c|}{ Validation } & \multirow{2}{*}{$\begin{array}{l}\text { Cutoff } \\
\text { points }\end{array}$} \\
\hline & Reliability & Validity & \\
\hline $\begin{array}{l}\text { Numerical } \\
\text { item: 1-5/ } \\
\text { total: } \\
\text { 8-40 }\end{array}$ & $\begin{array}{l}r=0.84 \\
p<0.01 \\
(n=50 \text { paired } \\
\text { obs) }\end{array}$ & $\begin{array}{l}\text { COMFORT } \\
\text { vs. VAS } \\
r=0.75 \\
p<0.01\end{array}$ & $\begin{array}{l}\text { OS } \leq 16 \\
\text { AS } 17-29 \\
\text { US } \geq 30\end{array}$ \\
\hline $\begin{array}{l}\text { Numerical } \\
\text { item: 1-5/ } \\
\text { total: } \\
6-30\end{array}$ & $\begin{array}{l}\text { Kappa = 0.77- } \\
1.0(n=40 \\
\text { paired obs }) \\
\text { ICC }=0.99\end{array}$ & $\begin{array}{l}\text { COMFORT } \\
\text { behavior } \\
\text { vs. NISS } \\
\text { (Kruskal- } \\
\text { Wallis, } \\
p<0.001 \text { ) }\end{array}$ & $\begin{array}{l}\text { OS } \leq 10 \\
\text { AS } 11-22 \\
\text { US } \geq 23\end{array}$ \\
\hline $\begin{array}{l}\text { Bipolar } \\
\text { numeric } \\
\text { Item: }-3 \\
\text { to }+1 / \\
\text { Total: }-21 \\
\text { to } 7\end{array}$ & $\begin{array}{l}\text { Kappa }=0.44- \\
0.76(n=198 \\
\text { paired obs) } \\
\text { ICC }=0.79\end{array}$ & $\begin{array}{l}\text { SBS vs. } \\
\text { NRS } \\
(F=75.8 \\
p<0.001)\end{array}$ & Not done \\
\hline
\end{tabular}

to 7

PICU, pediatric intensive care unit; VAS, visual analog scale; NISS, nurse interpretation sedation score; SBS, state behavior scale; NRS, numeric rating scale; kappa, linearly weighted Cohen's kappa; r, Pearson product correlation coefficient; obs, observations; OS, Oversedation; AS, Adequate sedation; US, undersedation; ICC, intraclass correlation coefficient. 


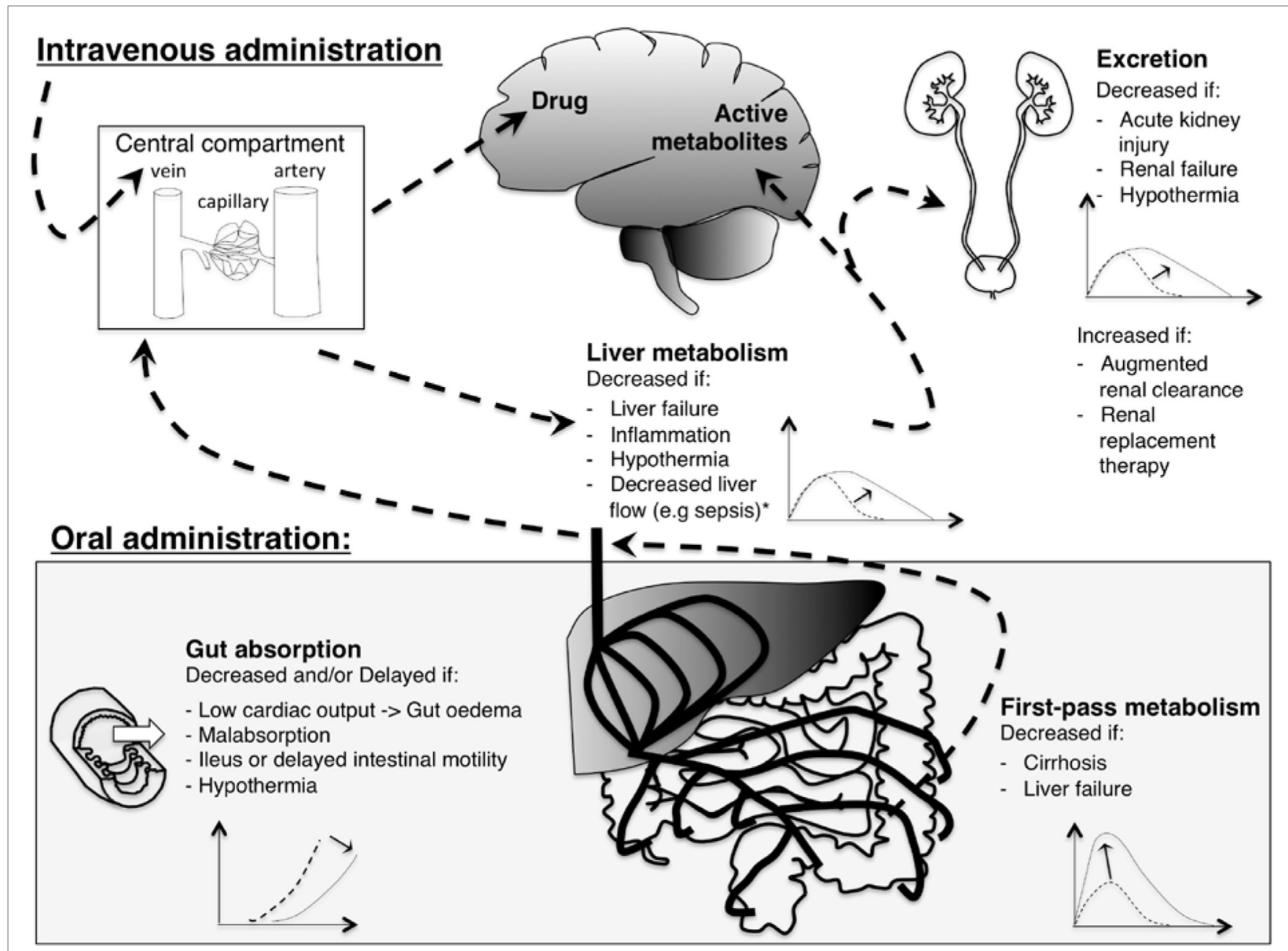

FIGURE 1 | Illustration of the effect of critical illness on pharmacokinetics of analgosedative drugs. With intravenous administration (upper left), drugs are injected directly into the central compartment: bioavailability is complete. With oral administration (lower left), gut absorption and first by-pass metabolism limit bioavailability. Analgosedative drugs are metabolized by the liver into more water-soluble metabolites that are excreted by the kidneys. Some analgosedatives have active metabolites (e.g., morphine and midazolam) that may accumulate with decreased renal function. A graphical representation of drug concentration over time depicts pharmacokinetics changes induced by critical illness: the dashed line represents the curve of a healthy individual while the solid line shows the change induced by critical illness. *Liver flow affects clearance of drugs with a high hepatic extraction ratio (e.g., propofol).

heart failure (altering absorption, distribution, drug metabolism and excretion). Extrinsic factors include treatment modalities such as extra-corporeal membrane oxygenation (ECMO), hypothermia, and continuous renal replacement therapy (18). Volume of distribution is often increased and clearance is altered either way in ECMO patients (19). Hypothermia leads to changes in volume of distribution due to redistribution of blood flow and a decreased clearance due to a decreased drug metabolizing enzyme activity $(20,21)$.

Furthermore, critical illness itself may be of influence on the effect of sedation. For instance, a critically ill child who is less reactive due to its underlying illness (e.g., sepsis) will respond differently to a sedative drug than a relatively healthy child who receives sedation for the acceptance of a tube after airway reconstruction.

Although the impact of separate aspects of critical illness on drug disposition is increasingly recognized, only few factors are actually taken into account in current dosing such as dosing adjustments with renal failure. For sedative drugs, this underscores the importance of dosing and titrating the drugs to effect.

\section{COMMONLY USED AGENTS}

An ideal sedative drug exhibits anxiolysis, amnesia, and analgesia qualities, should be easily titrated to effect, and without any adverse effects. However, none of the existing drugs does meet all these qualities. Therefore, medications are commonly co-administered to compensate for any shortcomings and to achieve an optimal effect.

In PICU, benzodiazepines and opioids are frequently used agents. Despite the widespread use of sedatives in PICU, highquality data supporting appropriate dosing and safety are lacking (22). Many commonly used sedatives and analgesics in the PICU 
(e.g., lorazepam, dexmedetomidine, and fentanyl) are still used off-label, which means that their efficacy and safety have not been adequately proven (23). A rational choice for a particular agent is based on the desired effect of the drug, the interaction of the patient's disease, and the side-effects of the drug (Table 2). These systemic effects can be adverse effects [e.g., propofol is avoided in patients with unstable hemodynamics due to its cardiodepressive properties (24)] or desired effects [ketamine is a bronchodilator used in asthma (25)]. Ideally, the choice for a particular agent should include its long-term effect on neurodevelopment. Most commonly used sedative and analgesics are neurotoxic in animals (26-28), which has caused uncertainty for their long-term safety in humans. Reassuringly, these animal data have not been confirmed in human studies. No adverse long-term effects of morphine administration at neonatal age were reported $(29,30)$. Moreover, short duration sevoflurane anesthesia in infancy does not appear to increase the risk of adverse neurodevelopmental outcome at 2 years of age compared with awake-regional anesthesia (31).

\section{Benzodiazepines}

Benzodiazepines (midazolam, and to a lesser extent lorazepam) are the most commonly used sedatives and the sedative of choice in many pediatric intensive cares (32). Midazolam is a central nervous system depressant that exerts its clinical effect by binding to a receptor complex, which facilitates the action of the inhibitory neurotransmitter gamma-amino butyric acid (GABA) in the brain. Through this effect, midazolam possesses sedative, anxiolytic, anticonvulsant, muscle relaxant, and amnesic properties (33). The amnesic effects of midazolam probably play an important role in the low levels of unpleasant experiences recalled by survivors of PICU treated with this agent (34).

Midazolam is metabolized to a major hydroxylated active metabolite (1-OH midazolam) by CYP3A4/5, and subsequently metabolized to 1-OH-midazolam-glucuronide by UGTs and renally excreted (35). A reduction of CYP3A activity as a result of inflammation, organ failure (36), or concomitant administration of other therapeutic drugs (drug-drug interactions) (37) may account for the failure of critically ill children to metabolize midazolam. In patients with renal failure, prolonged sedative effects may be caused by the accumulation of the active metabolite, 1-OH midazolam-glucuronide (38).

Although most commonly used, midazolam is certainly not an ideal sedative agent. Adverse events associated with its use are not only tolerance, dependence, and withdrawal but also paradoxical hyperactivity $(4,5)$. In adults, continuous benzodiazepine use is associated with prolonged mechanical ventilation and length of ICU stay (39). Also, hypotension may occur and is most likely with bolus administration, particularly in neonates, in the setting of hypovolemia or concomitant use of morphine (40).

Lorazepam is a long-acting benzodiazepine used orally and intravenously. The use of intravenous lorazepam is limited by the fact that it is dissolved in propylene glycol, which can accumulate to produce metabolic acidosis and renal dysfunction $(41,42)$. For weaning, oral lorazepam is a good alternative for midazolam, because of its long half-live.

\section{Opioids}

Although opioids are analgesic drugs, they have sedative effects. Some PICUs use morphine as a first-line sedative while others favor sedatives (mainly benzodiazepine) in the absence of suspected pain (43). Morphine provides sedation as well as analgesia and can be used as a single agent for analgesia and sedation.

As morphine clearance is substantially reduced in neonates less than 10 days of age, $1 / 3-1 / 2$ of dosing in older children is needed to reach the same plasma levels as in older children. For analgesia, this dose reduction is related to adequate analgesia, but sedation data are lacking (44). Morphine has a relatively long duration of action of around $2 \mathrm{~h}$ when administered as a single dose intravenously (peak analgesic effect after $20 \mathrm{~min}$ ). Morphine is characterized by hepatic metabolism (glucuronidation) and renal excretion with intermediate volume of distribution. Therefore, its effects can be prolonged in patients with renal impairment. The impact of liver failure seems mild or moderate at best (45). Morphine stimulates the release of histamine and inhibits compensatory sympathetic responses, leading to vasodilation and consequently hypotension, particularly following bolus administration (46). The opioid fentanyl has powerful analgesic properties and provides some sedation, as demonstrated in a randomized controlled trial comparing continuous fentanyl and remifentanil in postoperative orthopedic children (47). No studies are available for the use of fentanyl for long-term sedation in PICU. An important, but rare adverse effect is fentanyl-induced chest wall rigidity causing respiratory compromise, generally occurring after a large fentanyl bolus administration (48).

\section{Alpha-Agonists}

Clonidine and dexmedetomidine are central $\alpha-2$ agonists with sedative and analgesic properties (49) increasingly used as first-line sedatives or as adjunct to other sedatives. Enthusiasm for these agents is driven by the absence of clinically significant respiratory depression $(49,50)$, which is an advantage in the spontaneously breathing patient or when extubation is planned (51). Moreover, they do not show neurotoxicity in animals (52), have opioid and benzodiazepine sparing properties $(53,54)$, and may decrease the incidence of withdrawal and delirium (55). A RCT comparing continuous intravenous clonidine and midazolam in 129 ventilated children ( 30 days to 15 years) showed a similar sedative effect (56). Sedation under dexmedetomidine may more closely resemble natural sleep than sedation under benzodiazepines, although these theoretical advantages have not yet been demonstrated to improve patients' perception of sleep in adult $\operatorname{ICU}(57,58)$. For children, the use of dexmedetomidine is still off-label; it is approved for continuous sedative infusion in adults for $24 \mathrm{~h}$.

The main adverse effect of alpha agonists is bradycardia/ arythmia and hypotension $(49,59)$, but these effects are rarely of clinical significance $(54,56)$. Data in children with severe hemodynamic compromise are insufficient to recommend their use in this particular population. To date, no study compared dexmedetomidine to clonidine in the PICU. 
TABLE 2 | Drugs used for sedation in critically ill children and their PKPD considerations.

\begin{tabular}{|c|c|c|c|c|c|c|}
\hline & \multirow[t]{2}{*}{ Indications } & \multirow[t]{2}{*}{ Dose } & \multirow[t]{2}{*}{ Elimination/metabolism } & \multirow[t]{2}{*}{ Effect of age on PK/PD } & \multicolumn{2}{|c|}{$\begin{array}{l}\text { Dosing adjustment in organ } \\
\text { impairment }\end{array}$} \\
\hline & & & & & Liver $^{\mathrm{a}}$ & Renal \\
\hline \multicolumn{7}{|l|}{ Benzodiazepine } \\
\hline Midazolam & Sedation/amnesia & 50-300 mcg/kg/h i.v. & $\begin{array}{l}\text { Liver (CYP3A4/5) active metabolite: } \\
\text { 1-OH-midazolam and 1-OH-midazolam glucuronide }\end{array}$ & $\begin{array}{l}\text { CYP3A4/5 activity is low at birth and } \\
\text { reaches adult values in the first years of } \\
\text { life (106) }\end{array}$ & Consider (107) & $\begin{array}{l}\text { Yes, in severe renal } \\
\text { failure (108) }\end{array}$ \\
\hline Lorazepam & Sedation/amnesia & $0.01-0.1 \mathrm{mg} / \mathrm{kg} / \mathrm{h}$ i.v. & $\begin{array}{l}\text { Liver (glucuronidation by multiple UGT2B enzymes) } \\
\text { No active metabolite }\end{array}$ & $\begin{array}{l}\text { UGT2B7 low at birth and increases with } \\
\text { age (109) }\end{array}$ & Consider (110) & No (108) \\
\hline \multicolumn{7}{|c|}{$\alpha-2$ agonist } \\
\hline Dexmedetomidine & $\begin{array}{l}\text { Sedation and } \\
\text { analgesia }\end{array}$ & $0.2-0.7 \mathrm{mcg} / \mathrm{kg} / \mathrm{h}$ i.v. & $\begin{array}{l}\text { Liver (glucuronidation and mainly CYP2A6) } \\
\text { No active metabolite }\end{array}$ & $\begin{array}{l}\text { Decreased clearance in children }<1 \text { years } \\
\text { of age (111) }\end{array}$ & Yes & No \\
\hline Clonidine & $\begin{array}{l}\text { Sedation and } \\
\text { analgesia }\end{array}$ & $0.5-2.5 \mathrm{mcg} / \mathrm{kg} / \mathrm{h}$ i.v. & $\begin{array}{l}50 \% \text { renal elimination } / 50 \% \text { liver metabolism (mainly } \\
\text { CYP2D6) } \\
\text { No active metabolite }\end{array}$ & Decreased clearance in neonates & Consider & Yes/not significant \\
\hline Propofol & $\begin{array}{l}\text { Sedation and } \\
\text { hypnotic }\end{array}$ & $1-4 \mathrm{mg} / \mathrm{kg} / \mathrm{U}$ i.v. $<24 \mathrm{~h}$ duration & $\begin{array}{l}\text { Rapid and extensive liver metabolism (mainly } \\
\text { CYP2B6) } \\
\text { No active metabolite }\end{array}$ & $\begin{array}{l}\text { Preterm neonates and neonates in the } \\
\text { first week of life at increased risk for } \\
\text { accumulation (112) }\end{array}$ & $\begin{array}{l}\text { Consider (113, } \\
114)\end{array}$ & No \\
\hline S-ketamine & $\begin{array}{l}\text { Analgesia and } \\
\text { sedation }\end{array}$ & 1-3 mg/kg/h (sedation) & $\begin{array}{l}\text { Liver metabolism (demethylation and hydroxylation) } \\
\text { Active metabolite: norketamine (around three times } \\
\text { less potent than ketamine) }\end{array}$ & $\begin{array}{l}\text { Appears similar to adults from } 1 \text { week } \\
\text { onward (115) }\end{array}$ & $\begin{array}{l}\text { Hepatotoxic } \\
(116)\end{array}$ & No \\
\hline Pentobarbital & Sedation & $1-5 \mathrm{mg} / \mathrm{kg} / \mathrm{h}$ iv & $\begin{array}{l}\text { Liver (microsomal enzyme system) } \\
\text { No active metabolite }\end{array}$ & Reduced clearance in neonates (117) & Consider (118) & No (119) \\
\hline \multicolumn{7}{|l|}{ Opioids } \\
\hline Morphine & $\begin{array}{l}\text { Analgesia with } \\
\text { sedation }\end{array}$ & $5-40$ mcg $/ \mathrm{kg} / \mathrm{U}$ i.v. & Liver (glucuronidation by UGT2B7) & $\begin{array}{l}\text { Age-dependent increase in plasma } \\
\text { clearance in children younger than } \\
10 \text { years of age (109) }\end{array}$ & Consider (120) & $\begin{array}{l}\text { Initiate at lower } \\
\text { dose and titrate } \\
\text { slowly (121) }\end{array}$ \\
\hline & & & $\begin{array}{l}\text { Active metabolite: morphine-6-glucuronide (more } \\
\text { potent than morphine) }\end{array}$ & & & \\
\hline Fentanyl & $\begin{array}{l}\text { Analgesia and } \\
\text { sedation }\end{array}$ & $1-10 \mathrm{mcg} / \mathrm{kg} / \mathrm{h}$ iv & Liver (CYP3A4) & NA & Consider & Yes \\
\hline
\end{tabular}


TABLE 2 | Continued

\begin{tabular}{|c|c|c|c|c|}
\hline & ЕСMO & Hemodynamic tolerance & Relevant respiratory PD characteristics & Withdrawal \\
\hline \multicolumn{5}{|l|}{ Benzodiazepine } \\
\hline \multirow[t]{2}{*}{ Midazolam } & $\begin{array}{l}\text { Increased Vd and } \\
\text { drug loss in vitro } \\
(122,123)\end{array}$ & $\begin{array}{l}\text { Hypotension with bolus dosing } \\
\text { (124) }\end{array}$ & Respiratory depression & $++(5,83)$ \\
\hline & & Fall in cardiac output (125) & & \\
\hline Lorazepam & $\begin{array}{l}\text { High drug loss } \\
\text { in vitro (126) }\end{array}$ & Hypotension & Respiratory depression & $++(83)$ \\
\hline \multicolumn{5}{|c|}{$\alpha-2$ agonists } \\
\hline Dexmedetomidine & No data & $\begin{array}{l}\text { Bradycardia and hypotension } \\
\text { rarely of clinical significance }\end{array}$ & $\begin{array}{l}\text { No significant respiratory depression, useful for } \\
\text { extubation of in spontaneously breathing patient }\end{array}$ & $\begin{array}{l}\text { Rebound hypertension and possible withdrawal after prolonged infusion (weaning } \\
\text { required or switch to oral clonidine) (127) }\end{array}$ \\
\hline Clonidine & No data & Bradyarrhytmia has been reported & & Rebound hypertension and withdrawal (weaning required) \\
\hline \multirow[t]{2}{*}{ Propofol } & $\begin{array}{l}\text { High drug loss } \\
\text { in vitro }(19,128)\end{array}$ & Myocardial depressant & Respiratory depression & $\begin{array}{l}\text { Irritability, jitteriness, and agitation on abrupt discontinuation after prolonged } \\
\text { infusion (100) }\end{array}$ \\
\hline & No in vivo study & & $\begin{array}{l}\text { Very quick emergence by stopping, useful during } \\
\text { weaning of mechanical ventilation }\end{array}$ & \\
\hline \multirow[t]{2}{*}{ Ketamine } & No data & $\begin{array}{l}\text { Usually preserved hemodynamic } \\
\text { stability, but when endogenous } \\
\text { stores of catecholamines have } \\
\text { been depleted by stress or } \\
\text { chronic illness ketamine can } \\
\text { induce cardiovascular depression. }\end{array}$ & No respiratory depression & Delirium after prolonged use in adult \\
\hline & & & First-line sedative in asthma (Bronchodilator) & No data in PICU \\
\hline Barbiturate & $\begin{array}{l}\text { Increased Vd } \\
(129)\end{array}$ & $\begin{array}{l}\text { Hypotension, depression of } \\
\text { cardiac contractility }\end{array}$ & Respiratory depression & $++(73)$ \\
\hline \multicolumn{5}{|l|}{ Opioids } \\
\hline \multirow[t]{2}{*}{ Morphine } & $\begin{array}{l}\text { High drug loss } \\
\text { in vitro }(126,130)\end{array}$ & $\begin{array}{l}\text { Histamine release leading to } \\
\text { vasodilatation and hypotension, } \\
\text { particularly following bolus dose }\end{array}$ & Respiratory depression & $++(83)$ \\
\hline & $\begin{array}{l}\text { Clearance and Vd } \\
\text { changes during } \\
\text { prolonged ECMO } \\
\text { (131) }\end{array}$ & & $\begin{array}{l}\text { Use with caution in asthmatic patients due to } \\
\text { potential histamine release }\end{array}$ & \\
\hline Fentanyl & $\begin{array}{l}\text { High drug loss } \\
\text { in vitro }(123,130)\end{array}$ & $\begin{array}{l}\text { Large bolus doses can cause } \\
\text { hypotension }\end{array}$ & Respiratory depression & $++(83)$ \\
\hline
\end{tabular}

${ }^{a}$ All drugs that are significantly metabolized by the liver may need adjustment in fulminant acute liver failure, but not with mild increases of liver enzymes. Consider using only bolus doses and titrate to effect or use non-hepatically cleared drug like remifentanil. 


\section{Propofol}

Propofol has sedative and hypnotic properties. It involves GABA receptor activation (60) although its mechanism of action is not fully understood. Due to its strong cardio-depressant effect (24), its use should be avoided in the hemodynamically unstable patient. Long-term infusions in the PICU are contraindicated in the official drug label for children $<16$ years due the risk of lethal propofol infusion syndrome (PRIS). Any suspicion of PRIS (clinical and biological signs: metabolic acidosis, increased liver enzymes, lipemia, rhabdomyolysis, renal and cardiac failure) should lead to an immediate interruption of propofol infusion but despite discontinuation, death can ensue (61). Propofol infusion rate and duration, the presence of traumatic brain injury, and fever are factors associated with mortality in PRIS (62). The use of propofol should be limited; when used maximum infusion rate must not exceed $4 \mathrm{mg} / \mathrm{kg} / \mathrm{h}$ with a maximum duration of $24 \mathrm{~h}$ (62).

Propofol's very short half-live offers an advantage around the time of extubation (mainly in agitated patients): it allows weaning from the longer acting sedative inducing respiratory depression, control sedation during the time of extubation and ensure a quick recovery after. Therefore, in this special case, a short-term infusion of propofol can be considered.

\section{Ketamine}

Ketamine is an NMDA receptor antagonist (63) with cataleptic, amnestic, and analgesic properties. It maintains hemodynamics $(64,65)$ by inducing release of endogenous catecholamine (65). However, in patients with hemodynamic compromise and chronic illness or stress who have depleted catecholamine stores, it can decrease myocardial contractility and even induce collapse $(66,67)$. Ketamine is used in the PICU as a co-analgesic with opioids for pain control (low dose, around $0.1 \mathrm{mg} / \mathrm{kg} / \mathrm{h}$ ) (68) and occasionally when usual sedative agents fail to provide adequate sedation (high dose, $1-3 \mathrm{mg} / \mathrm{kg} / \mathrm{h}$ ). Due to its bronchodilatory properties, it is the first-line analgosedative in status asthmaticus $(25,69)$. A very common adverse effect of ketamine is the occurrence of hallucinations, and therefore low dose of benzodiazepines should be co-administered. Early work hints at its potential to elevate intracranial pressure (70) and many physicians still avoid its use in traumatic brain injury despite more recent work not showing this effect (71).

\section{Antihistamines}

Promethazine, alimemazine, and diphenhydramine are first generation antihistamines with anti-dopaminergic and anticholinergic drug actions. These drugs may produce significant sedation as well as quiescence. A combination of oral chloral hydrate and promethazine was more effective than midazolam infusion for maintenance sedation in critically ill children, but less than half the patients in each study arm reached target sedation during study period (72). No other studies are available, and therefore, evidence to use antihistamines for (long-term) sedation in PICU is low.

\section{Barbiturates}

Pentobarbital and thiopental are primarily used for therapy-resistant status epilepticus, but its use as sedative in therapy-resistant agitation has also been reported $(73,74)$. Barbiturates are highly lipid soluble. Given by infusion, it accumulates in adipose tissue whence it diffuses slowly back to the blood after infusion cessation. This, coupled with a long half-life $(5-10 \mathrm{~h})$, is responsible for the persistence of sedation after infusion cessation. Barbiturates are also associated with high rates of adverse events, including hypotension, depression of cardiac contractility, severe skin and mucous reactions (Stevens Johnson syndrome and Toxic Epidermal Necrolysis), and neurologic sequelae (73). Lifethreatening hypokalemia and rebound hyperkalemia have been observed after cessation of thiopentone coma for intracranial hypertension. As this has not been observed with other underlying diseases or with pentobarbital, its cause is likely due to an association between the underlying clinical symptoms and thiopentone (75).

\section{Neuro-Muscular Blockers}

Analgesia and profound sedation have to be ensured before starting neuromuscular blockade. Neuromuscular blocking agents are associated to critical illness polyneuropathy and myopathy and therefore should be restricted to special circumstances, discontinued as soon as possible and used at the smallest possible dose $(76,77)$. The level of evidence supporting their prolonged use for particular indications is poor $(76,78)$. They are recommended if effective mechanical ventilation cannot be achieved despite profound sedation [e.g., ARDS (77), severe asthma $(25,79)]$. They are often used in case of severe cardio-vascular instability, but their benefit may be limited because only modest decrease in energy consumption is achieved compared to profound sedation $(80,81)$. Other common uses are refractory pulmonary and intracranial hypertension (82).

\section{SEDATION STRATEGIES}

Optimizing sedation in the critically ill is of major importance. In general, the current tendency is to lighten sedation in the intensive care to avoid delayed recovery with longer duration of ventilation (2), tolerance, and withdrawal $(5,83)$. Despite the awareness of the adverse effects of oversedation, it remains common practice in the PICU (84). Sedation strategies play a key role to achieve adequate sedation (Box 1).

\section{Protocolized Sedation}

To optimize sedation in critically ill children, it is recommended to assess levels of sedation and to titrate sedatives and analgesics on the guidance of sedation protocols or algorithms. Implementing a sedation protocol allows targeting patient-specific sedation goals. In the adult intensive care, protocol implementation decreases days of mechanical ventilation and ICU stay (85). But more recently, adult studies failed to show these positive effects (86). These changes in results over time may be explained by the growing awareness of the deleterious effect of oversedation and general tendency to avoid it. In the PICU, the effect of protocolizing sedation is less clear, but studies are recent and avoidance of oversedation may already have entered the practice. Several non-randomized trials reported conflicting results on the impact of protocolized sedation on outcomes like length of PICU stay, 


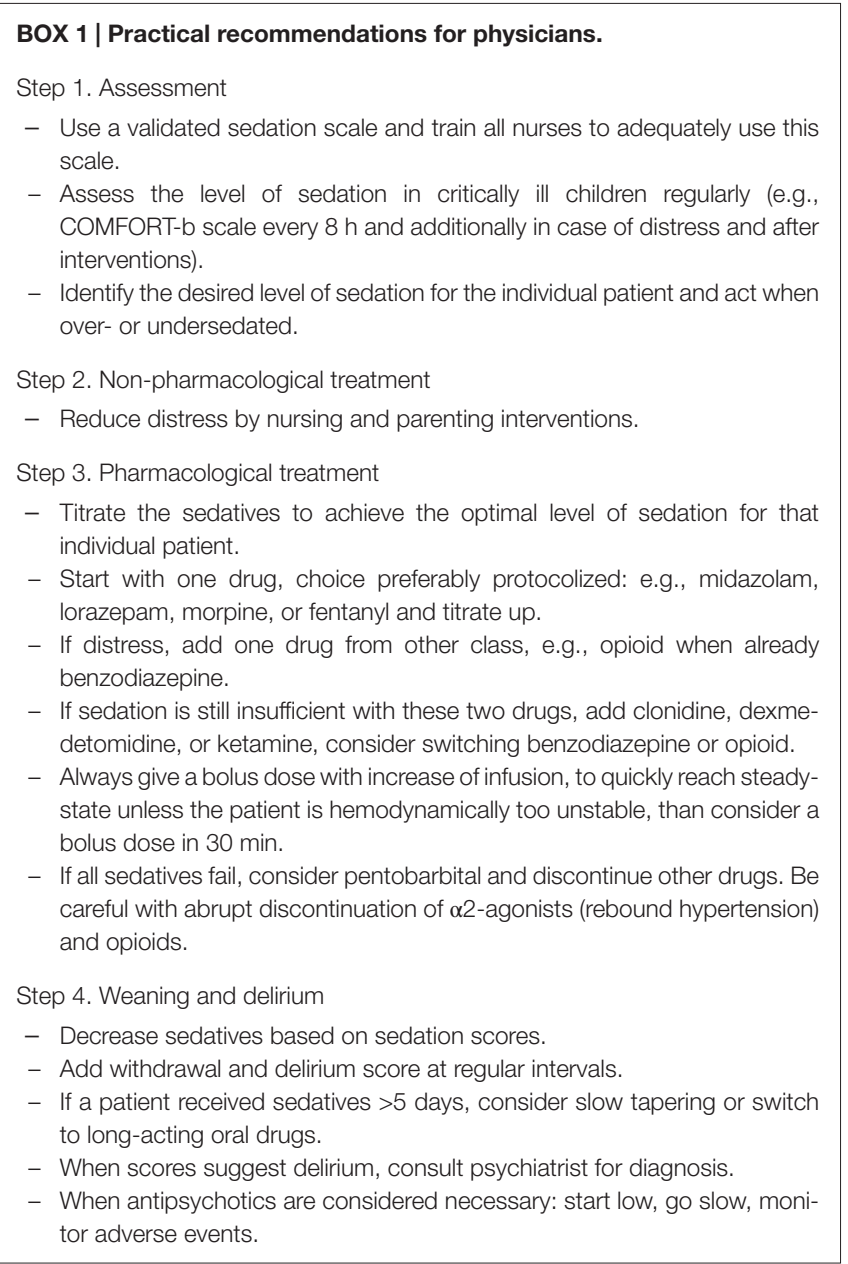

duration of mechanical ventilation, or the need for analgesia and sedation (87). Recently, in a large cluster randomized trial among children undergoing mechanical ventilation for acute respiratory failure, the use of a sedation protocol compared to usual sedation practice did not improve clinical outcome (88).

\section{Daily Sedation Interruption}

Another approach to potentially avoid the negative effects of oversedation, and especially the adverse effects of continuous benzodiazepine use, is daily sedation interruption (DSI). In adults, clinical trials have shown that DSI can reduce the duration of mechanical ventilation, hospital stay, and amount of sedatives administered, without compromising patient comfort or safety (89). Several later studies have confirmed this beneficial effect (90), whereas other studies, in different settings, showed no benefit $(91,92)$.

In critically ill children, two pilot studies showed that DSI is feasible and safe, even in ECMO patients, but both studies were not designed to detect differences in clinical outcome (93, 94). Another study, comparing DSI with continuous sedation in children, DSI led to improved clinical outcomes, including shorter durations of mechanical ventilation and PICU stay (95). In a recent study comparing DSI + protocolized sedation to protocolized sedation only, no beneficial effect of DSI was found (96). DSI did not reduce the duration of mechanical ventilation, length of stay, or the amounts of sedative drugs administered. There are important differences between these studies in study design (DSI and Standard of Care arm vs. DSI + protocolized sedation and protocolized sedation arm), setting (India vs. Europe), patient population (e.g., high incidence of neurotrauma vs. respiratory infection), and ICU practices (e.g., longer mean duration of mechanical ventilation, more sedatives and neuromuscular blockers administered in the first study) (97). For the latter study (DSI + PS vs. PS), the effect of protocolized sedation itself on the clinical endpoints might have outweighed the effect of DSI, as also demonstrated in adults (91).

\section{Drug Cycling}

Some PICUs use drug "cycling" or "rotation" as a method of decreasing the adverse effects of continuous sedation (98). This strategy is aimed at preventing tachyphylaxis and tolerance by "cycling" drug combinations. For example, an opioid and benzodiazepine regimen can be changed to ketamine and promethazine, followed by clonidine and chloral hydrate, all on a weekly basis. However, to the best of our knowledge, evidence supporting the beneficial effects of "cycling" is lacking.

\section{ADVERSE EFFECTS}

\section{Withdrawal}

Prolonged administration of analgesics and sedatives in critically ill children may induce drug tolerance and physical dependency. Abrupt discontinuation or too rapid weaning of these drugs in physically dependent children may cause withdrawal syndrome. Symptoms of benzodiazepines and opiates withdrawal can broadly be distinguished into three groups: (1) overstimulation of the central nervous system (e.g., agitation, tremors, anxiety, and hallucinations), (2) autonomous dysregulation (e.g., sweating, fever, tachycardia, and tachypnea), and (3) gastro-intestinal symptoms, which have only been described in opiate withdrawal (99). Withdrawal syndrome has been particularly reported after administration of opioids and benzodiazepines. The onset of withdrawal syndrome depends on the half-life of the drug and can be after $1 \mathrm{~h}$ or up to several days after discontinuation of these drugs (100). Both longer duration of administration and high total doses of opioids and/or benzodiazepines are clearly related with the occurrence of withdrawal syndrome in critically ill children, and may therefore be considered risk factors $(83,99)$. Moreover, the exact biochemical mechanisms responsible for the development of withdrawal syndrome remain unclear. The reported prevalence of withdrawal syndrome in critically ill children who had received benzodiazepines and/or opioids for 5 or more days ranges from 17 to $57 \%(99,101)$.

The development of pediatric scoring tools for withdrawal syndrome is a huge step forward. Two validated assessment tools for observing and identifying withdrawal syndrome after long-term use of benzodiazepines and opioids in PICU patients have been described. These are the Withdrawal Assessment Tool version-1 (WAT-1) and the Sophia Observation Withdrawal Symptoms-scale (SOS) (102-105). Table 3 provides details on 


\begin{tabular}{|c|c|c|c|c|c|c|c|}
\hline \multirow[t]{2}{*}{ Instrument } & \multirow[t]{2}{*}{ Population } & \multirow[t]{2}{*}{ Observation items } & \multicolumn{2}{|c|}{ Structure } & \multicolumn{2}{|r|}{ Psychometric evaluation } & \multirow{2}{*}{$\begin{array}{l}\text { Withdrawal } \\
\text { cut-off scores }\end{array}$} \\
\hline & & & Total items & Score-range & Reliability & Validity & \\
\hline $\begin{array}{l}\text { Withdrawal } \\
\text { Assessment } \\
\text { Tool version } \\
1 \text { (WAT-1) } \\
(102,103)\end{array}$ & Children & $\begin{array}{l}\text { Tremor } \\
\text { Uncoordinated/repetitive } \\
\text { movement } \\
\text { Yawning or sneezing } \\
\text { State } \\
\text { Loose/watery stools } \\
\text { Vomiting/retching/gagging } \\
\text { Temperature }>37.8^{\circ} \mathrm{C} \\
\text { Sweating } \\
\text { State } \\
\text { Startle to touch } \\
\text { Time to gain calm state }(\mathrm{SBS} \leq 0)\end{array}$ & 11 Numerical & $0-12$ & $\begin{array}{l}\text { Internal: PRINCALS, } 4 \text { factors } \\
\text { IRR } \\
N=30 \text { paired observations } \\
\text { ICC }=0.98 \\
\text { Cohen's kappa }=0.80\end{array}$ & $\begin{array}{l}\text { Construct: Sen. }=0.87, \text { Spec. }=0.88 \\
r_{s} \text { : } 0.80 \text { (between WAT-1 score and NRS-withdrawal) } \\
\text { Peak WAT-1 scores for each subject correlated moderately } \\
\text { with total cumulative opioid exposure }(r=0.23, p=0.009) \text {, } \\
\text { cumulative benzodiazepine preweaning }(r=0.30, p<0.001) \\
\text { and total ( } r=0.33, p<0.001 \text { ) exposure } \\
\text { Sensitivity to change } \\
N=51 \text { episodes of withdrawal (in } 21 \text { pts) WAT-1 score } \\
-\quad \text { before rescue therapy: } 6(4-8) \\
-\quad \text { after after rescue therapy: } 2(1-3) \text { (Wilcoxon-signed rank } \\
\quad \text { test } p<0.001 \text { ) }\end{array}$ & $\geq 3$ \\
\hline $\begin{array}{l}\text { Sophia } \\
\text { Observation } \\
\text { withdrawal } \\
\text { Symptoms- } \\
\text { scale (SOS) } \\
(104,105)\end{array}$ & Children & $\begin{array}{l}\text { Tachycardia, tachypnea, fever } \\
\left(\geq 38.5^{\circ}\right) \text {, sweating, agitation, } \\
\text { anxiety, tremors, increased } \\
\text { muscle tone, inconsolable crying, } \\
\text { grimacing, sleeplessness, motor } \\
\text { disturbance, hallucinations, } \\
\text { vomiting, and diarrhea }\end{array}$ & 15 Numerical & $0-15$ & $\begin{array}{l}\text { Internal: MDS, } 3 \text { dimensions } \\
\text { IRR: } N=23 \text { paired } \\
\text { observations, ICC }=0.97 \\
\text { Cohen's kappa }=0.73-1.0 \\
\text { (items) }\end{array}$ & $\begin{array}{l}\text { Construct } \\
85 \text { experts } \\
\text { Construct } \\
\text { Sen. }=0.83 \\
\text { Spec. }=0.93 \\
\left.r_{\mathrm{s}}: 0.5195 \% \mathrm{Cl} 0.32-0.66, p<0.001\right) \text { cumulative doses of } \\
\text { benzodiazepines } \\
r_{\mathrm{s}} \text { : } 0.39(95 \% \mathrm{Cl} 0.17-0.57, p<0.01) \text { cumulative doses of } \\
\text { opioids } \\
\text { Sensitivity to change } \\
\mathrm{N}=156 \text { paired SOS assessments in } 51 \mathrm{pts} \\
\text { Decrease SOS score: } 1.47(95 \% \mathrm{Cl},-1.91 \text { to }-1.04) \text { after } \\
\text { rescue therapy }\end{array}$ & $\geq 4$ \\
\hline
\end{tabular}


symptoms and psychometric properties of the WAT-1 and SOS. The WAT-1 is an 11-item scale and scores of three or higher (on a scale of $0-12$ ) which indicates that the child is suspected for withdrawal. The SOS consists of 15 items and is based on the underlying empirical structure of co-occurrences of withdrawal symptoms that experts considered relevant. A SOS score of 4 or higher reflect a high probability of withdrawal.

Strategies to reduce the prevalence of withdrawal syndrome should begin by making active efforts to reduce doses of benzodiazepines and/or opioids during the whole ICU course, and thereby preventing oversedation. As discussed above, DSI does not appear to add to protocolized sedation to reach this goal. Protocolized sedation targeting at conscious sedation appears at this time the best available approach.

A weaning strategy for gradual decreasing of opioid and/or benzodiazepine dosages once the patient is recovering may be effective to prevent withdrawal syndrome. Strategies include slowly tapering off the intravenous infusion rate over time, using an alternative route, e.g., enteral or subcutaneous, or transition to long acting drugs like methadone from morphine/fentanyl or lorazepam from midazolam. Disappointingly, little evidence is available on efficacy or safety of different weaning strategies. Weaning strategies ranging from 10 days to several months have been evaluated in observational (retrospective and prospective) studies (132-136). Two negative RCTs evaluated methadone weaning in 5 vs. 10 days (137) and a high- vs. low-dose methadone schedule in children (138). And while target drug levels for sedative and opioid dependence have been established for adults, they are lacking for children, as are PK data. Hence, we can not advise on the optimal weaning strategy or preferred drugs in pediatric ICU withdrawal.

Nevertheless, some suggestions to reduce withdrawal syndrome while avoiding unnecessary prolonged drug use can be made. First, awareness among clinicians on the risk factors for withdrawal symptoms may aid to prevent a too rapid reduction in drug doses. Moreover, it may lead to a faster switch from IV, short half life drugs to oral or subcutaneous, long half-life drugs. This may also facilitate faster ICU discharge. Second, regular monitoring of withdrawal symptoms with validated scales will also help to faster diagnose and treat withdrawal as well monitoring of the effect of interventions.

\section{Pediatric Delirium}

Pediatric intensive care staff has become more alert to the occurrence of delirium in their patients - not least since studies showed an estimated incidence of 4-29\% (139-141). The core diagnostic criteria for delirium are (a) disturbance of consciousness with reduced ability to focus, shift or maintain attention; (b) change in cognition (such as memory deficit, disorientation, language disturbance) or development of a perceptual disturbance; (c) the disturbance develops over a short period of time and tends to fluctuate during the course of the day. The pathogenesis of delirium is largely unknown. The sufferers may be hyperactive, hypoactive, or show signs of both states. Typical for the hypoactive delirium are slowed or sparse speech, hypoactive or slowed motor activity as well as lethargy or also described as reduced awareness or apathy. A number of delirium symptoms overlap with those observed in other conditions, such as pain and withdrawal syndrome (99).

Adults and children largely show the same symptoms although hallucinations, cognitive changes and hypoactive delirium are difficult to diagnose in the very young, preverbal PICU population. For this reason, PD is underdiagnosed in this age group $(139,141)$. Another reason is that nurses and physicians may not specifically focus on the symptoms of PD. Still, it is also possible to assess PD in this vulnerable age group by carefully observing behavior $(139,142,143)$. Diagnosing of PD in the PICU setting requires a reliable, validated, and clinically useful bedside tool that may also serve for screening and guiding of treatment. This is an area in full development but several suitable instruments are already available: the pediatric Confusion Assessment Method for ICU (pCAM-ICU) (141), the Cornwell Assessment Pediatric Delirium tool (CAP-D) $(140,144)$, and the Sophia Observation withdrawal Symptoms-Pediatric Delirium scale (SOS-PD) (145). Haloperidol and risperidone are antipsychotics used for delirium in critically ill children and also adults. To date, studies showing benefit of antipsychotics to prevent or treat ICU delirium are lacking. Moreover, in a retrospective cohort of critically ill children, almost $10 \%$ of children showed severe adverse events associated with haloperidol treatment, including extrapyramidal syndrome (146). Hence, while ICU delirium has been associated with an increased risk of mortality, it is unclear if the benefits of antipsychotic treatment outweigh the risks. In the Netherlands, the Dutch Pediatric Drug Handbook (www. kinderformularium.nl) advices a low haloperidol starting dose to be carefully titrated to effect, while diligently monitoring potential side effects.

\section{NON-PHARMACOLOGICAL APPROACH}

Drug therapy is the most obvious treatment modality of distress, withdrawal syndrome and delirium in critically ill children. Increasingly, the importance of non-pharmacological interventions is recognized. Such interventions use a multicomponent approach, which including repeated reorientation, early mobilization, noise reduction (use of ear plugs), and a non-pharmacological sleep management. We suppose that these interventions could reduce distress and delirium, but evidence is limited. However, common sense suggests that these interventions (for example, promoting orientation and day-night rhythm, and avoiding overstimulation by light and sounds) may be effective for children as well.

Another strategy is adaptation of the environment, like noise reduction. Noise is a major environmental factor to cause anxiety and sleep disturbance in critically ill patients (32). In a way, noise reduction could well be effective in decreasing anxiety. It would be worthwhile, therefore, to reduce noise in the PICU as much as possible. All in all, based on the limited evidence it is difficult to extrapolate the effectiveness from adults to children. However, common sense has it that most of the interventions, for example promoting orientation and day-night rhythm and avoiding overstimulation by light and sounds, may be suitable for children as well, so as to create a comfortably calm environment for child and parents. Adult data show a reduction in delirium 
rates with a multifaceted approach, not only including lighter sedation approaches, but also non-pharmacological changes as noise reduction and aids for patients to better orientate themselves (147).

\section{FUTURE RESEARCH}

Despite the widespread use of sedatives to facilitate mechanical ventilation in pediatric intensive care, evidence to guide clinical practice is remarkably scarce. Only few adequately powered, welldesigned RCTs to study efficacy and safety of individual drugs or their combinations have been performed. Several roadblocks to the conduct of these trails have been identified and should be taken into account with the design of future studies. Hence, robust study design including adequate power calculation, randomization procedures and blinding. (International) multi-center design is very likely needed to reach adequate sample size and high likelihood of generalizability. This adds complexity to the trial and asks a tremendous effort in training of local nurses, physicians and other study personnel. Validated sedation scales for the specific population, e.g., also taking into account age of patient and patient-controlled or nurse-controlled, must be used to assess sedation level in children.

Further, especially in critically ill children, "gate keeping," i.e., not including the sickest patients for fear of overburdening patients and parents, presents an important challenge toward adequate recruitment. But, previous studies have shown that these challenges can be overcome and taking them into account, future research could focus on the following aspects of pediatric sedation in the ICU:

- Does protocolized sedation indeed improve clinical outcome? Preferably, short-term outcomes like as ventilator-free days, extubation readiness, withdrawal syndrome and long-term outcomes, like neurodevelopmental outcome, occurrence of PTSD and quality of life should be evaluated. This should also

\section{REFERENCES}

1. Jacobi J, Fraser GL, Coursin DB, Riker RR, Fontaine D, Wittbrodt ET, et al. Clinical practice guidelines for the sustained use of sedatives and analgesics in the critically ill adult. Crit Care Med (2002) 30(1):119-41. doi:10.1097/00003246-200201000-00020

2. Randolph AG, Wypij D, Venkataraman ST, Hanson JH, Gedeit RG, Meert KL, et al. Effect of mechanical ventilator weaning protocols on respiratory outcomes in infants and children: a randomized controlled trial. JAMA (2002) 288(20):2561-8. doi:10.1001/jama.288.20.2561

3. Saliski M, Kudchadkar SR. Optimizing sedation management to promote early mobilization for critically ill children. J Pediatr Intensive Care (2015) 4(4):188-93. doi:10.1055/s-0035-1563543

4. Fonsmark L, Rasmussen YH, Carl P. Occurrence of withdrawal in critically ill sedated children. Crit Care Med (1999) 27(1):196-9. doi:10.1097/00003246-199901000-00052

5. Ista E, van Dijk M, Gamel C, Tibboel D, de Hoog M. Withdrawal symptoms in critically ill children after long-term administration of sedatives and/ or analgesics: a first evaluation. Crit Care Med (2008) 36(8):2427-32. doi:10.1097/CCM.0b013e318181600d be evaluated in RCTs aiming to study non-pharmacological and pharmacological interventions.

- What are optimal drug doses to be used in pharmacological trials? Can we target similar drug concentrations in all patients, or do different patients need different target concentrations, e.g., based on severity of disease, underlying disease? Before a RCT can start, PK data should be available, from the literature or from prospective observational studies to explore PK and $\mathrm{PD}$ of the future study drugs. Especially, data is missing to guide dosing during critical illness and associated treatment modalities (e.g., CVVH and ECMO).

- Using a good understanding of the drug's PK and preferably target concentration, these data should be used to design RCT's comparing sedation regimens. Ideally, the PKs of the sedative drugs are also studied in these trials to validate the dosing assumptions and better understand variability in response.

- Another underrated aspect of drug trials is the recording of adverse events. A prospective, well-designed approach to document adverse events, may also aid to balance efficacy and safety of the different sedation approaches and guide future treatment decisions.

- Industry-initiated trials follow strict regulatory guidelines for the performance of clinical trials, including adequate documentation of adverse events, according to good clinical practice guidelines with extensive monitoring. Traditionally, these have been weaker in investigator-initiated trials, due to a lack of oversight and funds. Hence, consulting with experts in regulatory drug trials is important to safe-guard the quality and thereby also the safety of participants, as well as the generalizability of the results.

\section{AUTHOR CONTRIBUTIONS}

All authors contributed to the draft and critical revision of the manuscript. The study was supervised by de Wildt.

6. Ramsay MA, Savege TM, Simpson BR, Goodwin R. Controlled sedation with alphaxalone-alphadolone. Br Med J (1974) 2(5920):656-9. doi:10.1136/ bmj.2.5920.656

7. Ely EW, Truman B, Shintani A, Thomason JW, Wheeler AP, Gordon S, et al. Monitoring sedation status over time in ICU patients: reliability and validity of the Richmond agitation-sedation scale (RASS). JAMA (2003) 289(22):2983-91. doi:10.1001/jama.289.22.2983

8. Sessler CN, Gosnell MS, Grap MJ, Brophy GM, O’Neal PV, Keane KA, et al. The Richmond agitation-sedation scale: validity and reliability in adult intensive care unit patients. Am J Respir Crit Care Med (2002) 166(10):1338-44. doi: $10.1164 / \mathrm{rccm} .2107138$

9. Ambuel B, Hamlett KW, Marx CM, Blumer JL. Assessing distress in pediatric intensive care environments: the COMFORT scale. J Pediatr Psychol (1992) 17(1):95-109. doi:10.1093/jpepsy/17.1.95

10. Marx CM, Smith PG, Lowrie LH, Hamlett KW, Ambuel B, Yamashita TS, et al. Optimal sedation of mechanically ventilated pediatric critical care patients. Crit Care Med (1994) 22(1):163-70. doi:10.1097/00003246-199401000-00029

11. Carnevale FA, Razack S. An item analysis of the COMFORT scale in a pediatric intensive care unit. Pediatr Crit Care Med (2002) 3(2):177-80. doi:10.1097/00130478-200204000-00016 
12. Ista E, van Dijk M, Tibboel D, de Hoog M. Assessment of sedation levels in pediatric intensive care patients can be improved by using the COMFORT "behavior" scale. Pediatr Crit Care Med (2005) 6(1):58-63. doi:10.1097/01. PCC.0000149318.40279.1A

13. Curley MA, Harris SK, Fraser KA, Johnson RA, Arnold JH. State behavioral scale: a sedation assessment instrument for infants and young children supported on mechanical ventilation. Pediatr Crit Care Med (2006) 7(2):107-14. doi:10.1097/00130478-200603000-00031

14. Valkenburg AJ, Boerlage AA, Ista E, Duivenvoorden HJ, Tibboel D, van Dijk M. The COMFORT-behavior scale is useful to assess pain and distress in 0- to 3-year-old children with Down syndrome. Pain (2011) 152(9):2059-64. doi:10.1016/j.pain.2011.05.001

15. Boerlage AA, Ista E, de Jong M, Tibboel D, van Dijk M. The COMFORT behavior scale: is a shorter observation period feasible? Pediatr Crit Care Med (2012) 13(2):e124-5. doi:10.1097/PCC.0b013e3182192d92

16. Boerlage AA, Ista E, Duivenvoorden HJ, de Wildt SN, Tibboel D, van Dijk M. The COMFORT behaviour scale detects clinically meaningful effects of analgesic and sedative treatment. Eur J Pain (2015) 19(4):473-9. doi:10.1002/ejp.569

17. Frankenberg-Schwager M, Frankenberg D, Harbich R. Different oxygen enhancement ratios for induced and unrejoined DNA double-strand breaks in eukaryotic cells. Radiat Res (1991) 128(3):243-50. doi:10.2307/3578046

18. Schetz M. Drug dosing in continuous renal replacement therapy: general rules. Curr Opin Crit Care (2007) 13(6):645-51. doi:10.1097/ MCC.0b013e3282f0a3d3

19. Wildschut ED, Ahsman MJ, Houmes RJ, Pokorna P, de Wildt SN, Mathot RA, et al. Pharmacotherapy in neonatal and pediatric extracorporeal membrane oxygenation (ECMO). Curr Drug Metab (2012) 13(6):767-77. doi:10.2174/138920012800840383

20. Pokorna P, Wildschut ED, Vobruba V, van den Anker JN, Tibboel D. The impact of hypothermia on the pharmacokinetics of drugs used in neonates and young infants. Curr Pharm Des (2015) 21(39):5705-24. doi:10.2174/138 1612821666150901110929

21. van den Broek MP, Groenendaal F, Egberts AC, Rademaker CM. Effects of hypothermia on pharmacokinetics and pharmacodynamics: a systematic review of preclinical and clinical studies. Clin Pharmacokinet (2010) 49(5):277-94. doi:10.2165/11319360-000000000-00000

22. Hartman ME, McCrory DC, Schulman SR. Efficacy of sedation regimens to facilitate mechanical ventilation in the pediatric intensive care unit: a systematic review. Pediatr Crit Care Med (2009) 10(2):246-55. doi:10.1097/ PCC.0b013e31819a3bb9

23. Czaja AS, Reiter PD, Schultz ML, Valuck RJ. Patterns of off-label prescribing in the pediatric intensive care unit and prioritizing future research. J Pediatr Pharmacol Ther (2015) 20(3):186-96. doi:10.5863/1551-6776-20.3.186

24. Brussel T, Theissen JL, Vigfusson G, Lunkenheimer PP, Van Aken H, Lawin P. Hemodynamic and cardiodynamic effects of propofol and etomidate: negative inotropic properties of propofol. Anesth Analg (1989) 69(1):35-40.

25. Nievas IF, Anand KJ. Severe acute asthma exacerbation in children: a stepwise approach for escalating therapy in a pediatric intensive care unit. J Pediatr Pharmacol Ther (2013) 18(2):88-104. doi:10.5863/1551-6776-18.2.88

26. Young C, Jevtovic-Todorovic V, Qin YQ, Tenkova T, Wang H, Labruyere J, et al. Potential of ketamine and midazolam, individually or in combination, to induce apoptotic neurodegeneration in the infant mouse brain. $\mathrm{Br}$ J Pharmacol (2005) 146(2):189-97. doi:10.1038/sj.bjp.0706301

27. Creeley C, Dikranian K, Dissen G, Martin L, Olney J, Brambrink A. Propofolinduced apoptosis of neurones and oligodendrocytes in fetal and neonatal rhesus macaque brain. Br J Anaesth (2013) 110(Suppl 1):i29-38. doi:10.1093/ bja/aet 173

28. Brambrink AM, Evers AS, Avidan MS, Farber NB, Smith DJ, Martin LD, et al. Ketamine-induced neuroapoptosis in the fetal and neonatal rhesus macaque brain. Anesthesiology (2012) 116(2):372-84. doi:10.1097/ ALN.0b013e318242b2cd

29. Valkenburg AJ, van den Bosch GE, de Graaf J, van Lingen RA, Weisglas-Kuperus N, van Rosmalen J, et al. Long-term effects of neonatal morphine infusion on pain sensitivity: follow-up of a randomized controlled trial. J Pain (2015) 16(9):926-33. doi:10.1016/j.jpain.2015.06.007

30. van den Bosch GE, IJsselstijn H, van der Lugt A, Tibboel D, van Dijk M, White T. Neuroimaging, pain sensitivity, and neuropsychological functioning in school-age neonatal extracorporeal membrane oxygenation survivors exposed to opioids and sedatives. Pediatr Crit Care Med (2015) 16(7):652-62. doi:10.1097/PCC.0000000000000474

31. Davidson AJ, Disma N, de Graaff JC, Withington DE, Dorris L, Bell G, et al. Neurodevelopmental outcome at 2 years of age after general anaesthesia and awake-regional anaesthesia in infancy (GAS): an international multicentre, randomised controlled trial. Lancet (2016) 387(10015):239-50. doi:10.1016/ S0140-6736(15)00608-X

32. Kudchadkar SR, Yaster M, Punjabi NM. Sedation, sleep promotion, and delirium screening practices in the care of mechanically ventilated children: a wake-up call for the pediatric critical care community ${ }^{*}$. Crit Care Med (2014) 42(7):1592-600. doi:10.1097/CCM.0000000000000326

33. Blumer JL. Clinical pharmacology of midazolam in infants and children. Clin Pharmacokinet (1998) 35(1):37-47. doi:10.2165/00003088-199835010-00003

34. Playfor SD, Thomas DA, Choonara II. Recall following paediatric intensive care. Paediatr Anaesth (2000) 10(6):703-4. doi:10.1046/j.1460-9592.2000. ab01ad.x

35. GorskiJC, Hall SD, Jones DR, VandenBranden M, Wrighton SA. Regioselective biotransformation of midazolam by members of the human cytochrome P450 3A (CYP3A) subfamily. Biochem Pharmacol (1994) 47(9):1643-53. doi:10.1016/0006-2952(94)90543-6

36. Vet NJ, Brussee JM, de Hoog M, Mooij MG, Verlaat CW, Jerchel IS, et al. Inflammation and organ failure severely affect midazolam clearance in critically ill children. Am J Respir Crit Care Med (2016) 194(1):58-66. doi:10.1164/rccm.201510-21140C

37. Rendic S. Summary of information on human CYP enzymes: human P450 metabolism data. Drug Metab Rev (2002) 34(1-2):83-448. doi:10.1081/ DMR-120001392

38. Bauer TM, Ritz R, Haberthur C, Ha HR, Hunkeler W, Sleight AJ, et al. Prolonged sedation due to accumulation of conjugated metabolites of midazolam. Lancet (1995) 346(8968):145-7. doi:10.1016/S0140-6736(95)91209-6

39. Kollef MH, Levy NT, Ahrens TS, Schaiff R, Prentice D, Sherman G. The use of continuous i.v. sedation is associated with prolongation of mechanical ventilation. Chest (1998) 114(2):541-8. doi:10.1378/chest.114.2.541

40. Anand KJ, Hall RW, Desai N, Shephard B, Bergqvist LL, Young TE, et al. Effects of morphine analgesia in ventilated preterm neonates: primary outcomes from the NEOPAIN randomised trial. Lancet (2004) 363(9422):1673-82. doi:10.1016/S0140-6736(04)16251-X

41. Yahwak JA, Riker RR, Fraser GL, Subak-Sharpe S. Determination of a lorazepam dose threshold for using the osmol gap to monitor for propylene glycol toxicity. Pharmacotherapy (2008) 28(8):984-91. doi:10.1592/ phco.28.8.984

42. Chicella M, Jansen P, Parthiban A, Marlowe KF, Bencsath FA, Krueger KP, et al. Propylene glycol accumulation associated with continuous infusion of lorazepam in pediatric intensive care patients. Crit Care Med (2002) 30(12):2752-6. doi:10.1097/00003246-200212000-00021

43. Silvasi DL, Rosen DA, Rosen KR. Continuous intravenous midazolam infusion for sedation in the pediatric intensive care unit. Anesth Analg (1988) 67(3):286-8. doi:10.1213/00000539-198803000-00015

44. Krekels EH, Tibboel D, de Wildt SN, Ceelie I, Dahan A, van Dijk M, et al. Evidence-based morphine dosing for postoperative neonates and infants. Clin Pharmacokinet (2014) 53(6):553-63. doi:10.1007/s40262-014-0135-4

45. Horn E, Nesbit SA. Pharmacology and pharmacokinetics of sedatives and analgesics. Gastrointest Endosc Clin NAm (2004) 14(2):247-68. doi:10.1016/j. giec.2004.01.001

46. Rosow CE, Moss J, Philbin DM, Savarese JJ. Histamine release during morphine and fentanyl anesthesia. Anesthesiology (1982) 56(2):93-6. doi:10.1097/00000542-198202000-00003

47. Akinci SB, Kanbak M, Guler A, Aypar U. Remifentanil versus fentanyl for short-term analgesia-based sedation in mechanically ventilated postoperative children. Paediatr Anaesth (2005) 15(10):870-8. doi:10.1111/j.1460-9592.2005.01574.x

48. Coruh B, Tonelli MR, Park DR. Fentanyl-induced chest wall rigidity. Chest (2013) 143(4):1145-6. doi:10.1378/chest.12-2131

49. Ebert TJ, Hall JE, Barney JA, Uhrich TD, Colinco MD. The effects of increasing plasma concentrations of dexmedetomidine in humans. Anesthesiology (2000) 93(2):382-94. doi:10.1097/00000542-200008000-00016

50. Pichot C, Ghignone M, Quintin L. Dexmedetomidine and clonidine: from second- to first-line sedative agents in the critical care setting? J Intensive Care Med (2012) 27(4):219-37. doi:10.1177/0885066610396815 
51. Walker J, Maccallum M, Fischer C, Kopcha R, Saylors R, McCall J. Sedation using dexmedetomidine in pediatric burn patients. J Burn Care Res (2006) 27(2):206-10. doi:10.1097/01.BCR.0000200910.76019.CF

52. Zhang Y. Clonidine preconditioning decreases infarct size and improves neurological outcome from transient forebrain ischemia in the rat. Neuroscience (2004) 125(3):625-31. doi:10.1016/j.neuroscience.2004.02.011

53. Gupta P, Whiteside W, Sabati A, Tesoro TM, Gossett JM, Tobias JD, et al. Safety and efficacy of prolonged dexmedetomidine use in critically ill children with heart disease*. Pediatr Crit Care Med (2012) 13(6):660-6. doi:10.1097/ PCC.0b013e318253c7f1

54. Hunseler C, Balling G, Rohlig C, Blickheuser R, Trieschmann U, Lieser U, et al. Continuous infusion of clonidine in ventilated newborns and infants: a randomized controlled trial. Pediatr Crit Care Med (2014) 15(6):511-22. doi:10.1097/PCC.0000000000000151

55. Aydogan MS, Korkmaz MF, Ozgul U, Erdogan MA, Yucel A, Karaman A, et al. Pain, fentanyl consumption, and delirium in adolescents after scoliosis surgery: dexmedetomidine vs midazolam. Paediatr Anaesth (2013) 23(5):446-52. doi:10.1111/pan.12128

56. Wolf A, McKay A, Spowart C, Granville H, Boland A, Petrou S, et al. Prospective multicentre randomised, double-blind, equivalence study comparing clonidine and midazolam as intravenous sedative agents in critically ill children: the SLEEPS (safety profile, efficacy and equivalence in paediatric intensive care sedation) study. Health Technol Assess (2014) 18(71):1-212. doi: $10.3310 /$ hta 18710

57. Weinhouse GL, Watson PL. Sedation and sleep disturbances in the ICU. Anesthesiol Clin (2011) 29(4):675-85. doi:10.1016/j.anclin.2011.09.007

58. Corbett SM, Rebuck JA, Greene CM, Callas PW, Neale BW, Healey MA, et al. Dexmedetomidine does not improve patient satisfaction when compared with propofol during mechanical ventilation. Crit Care Med (2005) 33(5):940-5. doi:10.1097/01.CCM.0000162565.18193.E5

59. Tobias JD, Gupta P, Naguib A, Yates AR. Dexmedetomidine: applications for the pediatric patient with congenital heart disease. Pediatr Cardiol (2011) 32(8):1075-87. doi:10.1007/s00246-011-0092-8

60. Alkire MT, Haier RJ. Correlating in vivo anaesthetic effects with ex vivo receptor density data supports a GABAergic mechanism of action for propofol, but not for isoflurane. Br J Anaesth (2001) 86(5):618-26. doi:10.1093/ bja/86.5.618

61. Veldhoen ES, Hartman BJ, van Gestel JP. Monitoring biochemical parameters as an early sign of propofol infusion syndrome: false feeling of security. Pediatr Crit Care Med (2009) 10(2):e19-21. doi:10.1097/PCC.0b013e3181956bda

62. Krajcova A, Waldauf P, Andel M, Duska F. Propofol infusion syndrome: a structured review of experimental studies and 153 published case reports. Crit Care (2015) 19:398. doi:10.1186/s13054-015-1112-5

63. Kurdi MS, Theerth KA, Deva RS. Ketamine: current applications in anesthesia, pain, and critical care. Anesth Essays Res (2014) 8(3):283-90. doi:10.4103/0259-1162.143110

64. Audenaert SM, Wagner Y, Montgomery CL, Lock RL, Colclough G, Kuhn RJ, et al. Cardiorespiratory effects of premedication for children. Anesth Analg (1995) 80(3):506-10. doi:10.1213/00000539-199503000-00012

65. Haas DA, Harper DG. Ketamine: a review of its pharmacologic properties and use in ambulatory anesthesia. Anesth Prog (1992) 39(3):61-8.

66. Dewhirst E, Frazier WJ, Leder M, Fraser DD, Tobias JD. Cardiac arrest following ketamine administration for rapid sequence intubation. J Intensive Care Med (2013) 28(6):375-9. doi:10.1177/0885066612448732

67. Waxman K, Shoemaker WC, Lippmann M. Cardiovascular effects of anesthetic induction with ketamine. Anesth Analg (1980) 59(5):355-8. doi:10.1213/00000539-198005000-00007

68. Dahmani S, Michelet D, Abback PS, Wood C, Brasher C, Nivoche Y, et al. Ketamine for perioperative pain management in children: a meta-analysis of published studies. Paediatr Anaesth (2011) 21(6):636-52. doi:10.1111/j.1460-9592.2011.03566.x

69. Koninckx M, Buysse C, de Hoog M. Management of status asthmaticus in children. Paediatr Respir Rev (2013) 14(2):78-85. doi:10.1016/j.prrv.2013.03.003

70. Takeshita H, Okuda Y, Sari A. The effects of ketamine on cerebral circulation and metabolism in man. Anesthesiology (1972) 36(1):69-75. doi:10.1097/00000542-197201000-00013

71. Bar-Joseph G, Guilburd Y, Tamir A, Guilburd JN. Effectiveness of ketamine in decreasing intracranial pressure in children with intracranial hypertension. J Neurosurg Pediatr (2009) 4(1):40-6. doi:10.3171/2009.1.PEDS08319
72. Parkinson L, Hughes J, Gill A, Billingham I, Ratcliffe J, Choonara I. A randomized controlled trial of sedation in the critically ill. Paediatr Anaesth (1997) 7(5):405-10. doi:10.1046/j.1460-9592.1997.d01-109.x

73. Yanay O, Brogan TV, Martin LD. Continuous pentobarbital infusion in children is associated with high rates of complications. J Crit Care (2004) 19(3):174-8. doi:10.1016/j.jcrc.2004.07.008

74. Tobias JD, Deshpande JK, Pietsch JB, Wheeler TJ, Gregory DF. Pentobarbital sedation for patients in the pediatric intensive care unit. South Med J (1995) 88(3):290-4. doi:10.1097/00007611-199503000-00008

75. Bauke J. [Cytogenetic follow-up studies in chronic myelocytic leukemia]. Verh Dtsch Ges Inn Med (1971) 77:80-3.

76. PlayforS, JenkinsI,Boyles C,ChoonaraI,Davies G,HaywoodT,etal.Consensus guidelines for sustained neuromuscular blockade in critically ill children. Paediatr Anaesth (2007) 17(9):881-7. doi:10.1111/j.1460-9592.2007.02313.x

77. Valentine SL, Nadkarni VM, Curley MA. Pediatric acute lung injury consensus conference G. Nonpulmonary treatments for pediatric acute respiratory distress syndrome: proceedings from the pediatric acute lung injury consensus conference. Pediatr Crit Care Med (2015) 16(5 Suppl 1):S73-85. doi:10.1097/PCC.0000000000000435

78. Honsel M, Giugni C, Brierley J. Limited professional guidance and literature are available to guide the safe use of neuromuscular block in infants. Acta Paediatr (2014) 103(9):e370-3. doi:10.1111/apa.12682

79. Newth CJ, Meert KL, Clark AE, Moler FW, Zuppa AF, Berg RA, et al. Fatal and near-fatal asthma in children: the critical care perspective. J Pediatr (2012) 161(2):214.e-21.e. doi:10.1016/j.jpeds.2012.02.041

80. Lemson J, Driessen JJ, van der Hoeven JG. The effect of neuromuscular blockade on oxygen consumption in sedated and mechanically ventilated pediatric patients after cardiac surgery. Intensive Care Med (2008) 34(12):2268-72. doi:10.1007/s00134-008-1252-z

81. Vernon DD, WitteMK. Effect of neuromuscularblockade on oxygen consumption and energy expenditure in sedated, mechanically ventilated children. Crit Care Med (2000) 28(5):1569-71. doi:10.1097/00003246-20000500000051

82. Kochanek PM, Carney N, Adelson PD, Ashwal S, Bell MJ, Bratton S, et al. Guidelines for the acute medical management of severe traumatic brain injury in infants, children, and adolescents - second edition. Pediatr Crit Care Med (2012) 13(Suppl 1):S1-82. doi:10.1097/PCC.0b013e318259ee85

83. Best KM, Boullata JI, Curley MA. Risk factors associated with iatrogenic opioid and benzodiazepine withdrawal in critically ill pediatric patients: a systematic review and conceptual model. Pediatr Crit Care Med (2015) 16(2):175-83. doi:10.1097/PCC.0000000000000306

84. Vet NJ, Ista E, de Wildt SN, van Dijk M, Tibboel D, de Hoog M. Optimal sedation in pediatric intensive care patients: a systematic review. Intensive Care Med (2013) 39(9):1524-34. doi:10.1007/s00134-013-2971-3

85. Brook AD, Ahrens TS, Schaiff R, Prentice D, Sherman G, Shannon W, et al. Effect of a nursing-implemented sedation protocol on the duration of mechanical ventilation. Crit Care Med (1999) 27(12):2609-15. doi:10.1097/00003246-199912000-00001

86. Bucknall TK, Manias E, Presneill JJ. A randomized trial of protocol-directed sedation management for mechanical ventilation in an Australian intensive care unit. Crit Care Med (2008) 36(5):1444-50. doi:10.1097/ CCM.0b013e318168f82d

87. Poh YN, Poh PF, Buang SN, Lee JH. Sedation guidelines, protocols, and algorithms in PICUs: a systematic review. Pediatr Crit Care Med (2014) 15(9):885-92. doi:10.1097/PCC.0000000000000255

88. Curley MA, Wypij D, Watson RS, Grant MJ, Asaro LA, Cheifetz IM, et al. Protocolized sedation vs usual care in pediatric patients mechanically ventilated for acute respiratory failure: a randomized clinical trial. JAMA (2015) 313(4):379-89. doi:10.1001/jama.2014.18399

89. Kress JP, Pohlman AS, O'Connor MF, Hall JB. Daily interruption of sedative infusions in critically ill patients undergoing mechanical ventilation. $N$ Engl J Med (2000) 342(20):1471-7. doi:10.1056/NEJM200005183422002

90. Girard TD, Kress JP, Fuchs BD, Thomason JW, Schweickert WD, Pun BT, et al. Efficacy and safety of a paired sedation and ventilator weaning protocol for mechanically ventilated patients in intensive care (awakening and breathing controlled trial): a randomised controlled trial. Lancet (2008) 371(9607):126-34. doi:10.1016/S0140-6736(08)60105-1

91. Mehta S, Burry L, Cook D, Fergusson D, Steinberg M, Granton J, et al. Daily sedation interruption in mechanically ventilated critically ill patients cared 
for with a sedation protocol: a randomized controlled trial. JAMA (2012) 308(19):1985-92. doi:10.1001/jama.2012.13872

92. Anifantaki S, Prinianakis G, Vitsaksaki E, Katsouli V, Mari S, Symianakis A, et al. Daily interruption of sedative infusions in an adult medical-surgical intensive care unit: randomized controlled trial. JAdv Nurs (2009) 65(5):1054-60. doi:10.1111/j.1365-2648.2009.04967.x

93. Verlaat CW, Heesen GP, Vet NJ, de Hoog M, van der Hoeven JG, Kox M, et al. Randomized controlled trial of daily interruption of sedatives in critically ill children. Paediatr Anaesth (2014) 24(2):151-6. doi:10.1111/pan.12245

94. Wildschut ED, Hanekamp MN, Vet NJ, Houmes RJ, Ahsman MJ, Mathot RA, et al. Feasibility of sedation and analgesia interruption following cannulation in neonates on extracorporeal membrane oxygenation. Intensive Care Med (2010) 36(9):1587-91. doi:10.1007/s00134-010-1931-4

95. Gupta K, Gupta VK, Jayashree M, Singhi S. Randomized controlled trial of interrupted versus continuous sedative infusions in ventilated children. Pediatr Crit Care Med (2012) 13(2):131-5. doi:10.1097/PCC.0b013e31820aba48

96. Vet NJ, de Wildt SN, Verlaat CW, Knibbe CA, Mooij MG, van Woensel $\mathrm{JB}$, et al. A randomized controlled trial of daily sedation interruption in critically ill children. Intensive Care Med (2016) 42(2):233-44. doi:10.1007/ s00134-015-4136-z

97. Vet NJ, Verlaat CW, de Wildt SN, Tibboel D, de Hoog M. Daily interruption of sedation in critically ill children. Pediatr Crit Care Med (2012) 13(1):122. doi:10.1097/PCC.0b013e31822f1109

98. Playfor SD, Thomas DA, Choonara I. Sedation and neuromuscular blockade in paediatric intensive care: a review of current practice in the UK. Paediatr Anaesth (2003) 13(2):147-51. doi:10.1046/j.1460-9592.2003.00989.x

99. Ista E, van Dijk M, Gamel C, Tibboel D, de Hoog M. Withdrawal symptoms in children after long-term administration of sedatives and/or analgesics: a literature review. "Assessment remains troublesome". Intensive Care Med (2007) 33(8):1396-406. doi:10.1007/s00134-007-0696-x

100. Tobias JD. Tolerance, withdrawal, and physical dependency after long-term sedation and analgesia of children in the pediatric intensive care unit. Crit Care Med (2000) 28(6):2122-32. doi:10.1097/00003246-200006000-00079

101. Anand KJ, Willson DF, Berger J, Harrison R, Meert KL, Zimmerman J, et al. Tolerance and withdrawal from prolonged opioid use in critically ill children. Pediatrics (2010) 125(5):e1208-25. doi:10.1542/peds.2009-0489

102. Franck LS, Harris SK, Soetenga DJ, Amling JK, Curley MA. The withdrawal assessment tool-1 (WAT-1): an assessment instrument for monitoring opioid and benzodiazepine withdrawal symptoms in pediatric patients. Pediatr Crit Care Med (2008) 9(6):573-80. doi:10.1097/PCC.0b013e31818c8328

103. Franck LS, Scoppettuolo LA, Wypij D, Curley MA. Validity and generalizability of the withdrawal assessment tool-1 (WAT-1) for monitoring iatrogenic withdrawal syndrome in pediatric patients. Pain (2012) 153(1):142-8. doi:10.1016/j.pain.2011.10.003

104. Ista E, de Hoog M, Tibboel D, Duivenvoorden HJ, van Dijk M. Psychometric evaluation of the Sophia observation withdrawal symptoms scale in critically ill children. Pediatr Crit Care Med (2013) 14(8):761-9. doi:10.1097/ PCC.0b013e31829f5be1

105. Ista E, van Dijk M, de Hoog M, Tibboel D, Duivenvoorden HJ. Construction of the Sophia observation withdrawal symptoms-scale (SOS) for critically ill children. Intensive Care Med (2009) 35(6):1075-81. doi:10.1007/ s00134-009-1487-3

106. Ince I, Knibbe CA, Danhof M, de Wildt SN. Developmental changes in the expression and function of cytochrome P450 3A isoforms: evidence from in vitro and in vivo investigations. Clin Pharmacokinet (2013) 52(5):333-45. doi:10.1007/s40262-013-0041-1

107. Pentikainen PJ, Valisalmi L, Himberg JJ, Crevoisier C. Pharmacokinetics of midazolam following intravenous and oral administration in patients with chronic liver disease and in healthy subjects. J Clin Pharmacol (1989) 29(3):272-7. doi:10.1002/j.1552-4604.1989.tb03327.x

108. Bennett WM. Drug prescribing in renal failure. Drugs (1979) 17(2):111-23. doi:10.2165/00003495-197917020-00002

109. Kearns GL, Abdel-Rahman SM, Alander SW, Blowey DL, Leeder JS, Kauffman RE. Developmental pharmacology - drug disposition, action, and therapy in infants and children. N Engl J Med (2003) 349(12):1157-67. doi:10.1056/NEJMra035092

110. Kraus JW, Desmond PV, Marshall JP, Johnson RF, Schenker S, Wilkinson GR. Effects of aging and liver disease on disposition of lorazepam. Clin Pharmacol Ther (1978) 24(4):411-9. doi:10.1002/cpt1978244411
111. Potts AL, Anderson BJ, Warman GR, Lerman J, Diaz SM, Vilo S. Dexmedetomidine pharmacokinetics in pediatric intensive care - a pooled analysis. Paediatr Anaesth (2009) 19(11):1119-29. doi:10.1111/j.1460-9592. 2009.03133.x

112. Allegaert K, Peeters MY, Verbesselt R, Tibboel D, Naulaers G, de Hoon JN, et al. Inter-individual variability in propofol pharmacokinetics in preterm and term neonates. Br J Anaesth (2007) 99(6):864-70. doi:10.1093/bja/ aem 294

113. Tanaka N, Horiuchi A, Nakayama Y, Katsuyama Y, Isobe M, Aoyama T, et al. Safety and effectiveness of low-dose propofol sedation during and after esophagogastroduodenoscopy in child A and B cirrhotic patients. Dig Dis Sci (2013) 58(5):1383-9. doi:10.1007/s10620-012-2483-y

114. Servin F, Cockshott ID, Farinotti R, Haberer JP, Winckler C, Desmonts JM. Pharmacokinetics of propofol infusions in patients with cirrhosis. Br J Anaesth (1990) 65(2):177-83. doi:10.1093/bja/65.2.177

115. Hartvig P, Larsson E, Joachimsson PO. Postoperative analgesia and sedation following pediatric cardiac surgery using a constant infusion of ketamine. J Cardiothorac Vasc Anesth (1993) 7(2):148-53. doi:10.1016/10530770(93)90207-2

116. Niesters M, Martini C, Dahan A. Ketamine for chronic pain: risks and benefits. Br J Clin Pharmacol (2014) 77(2):357-67. doi:10.1111/bcp.12094

117. Pitlick W, Painter M, Pippenger C. Phenobarbital pharmacokinetics in neonates. Clin Pharmacol Ther (1978) 23(3):346-50. doi:10.1002/cpt1978233346

118. von Oldershausen HF, Held $\mathrm{H}$, Remmer H. [The break-down of pentobarbital in hepatic diseases]. Klin Wochenschr (1970) 48(9):565-7.

119. Reidenberg MM, Lowenthal DT, Briggs W, Gasparo M. Pentobarbital elimination in patients with poor renal function. Clin Pharmacol Ther (1976) 20(1):67-71. doi:10.1002/cpt197620167

120. Mazoit JX, Sandouk P, Zetlaoui P, Scherrmann JM. Pharmacokinetics of unchanged morphine in normal and cirrhotic subjects. Anesth Analg (1987) 66(4):293-8. doi:10.1213/00000539-198704000-00001

121. Ball M, McQuay HJ, Moore RA, Allen MC, Fisher A, Sear J. Renal failure and the use of morphine in intensive care. Lancet (1985) 1(8432):784-6. doi:10.1016/S0140-6736(85)91448-5

122. Ahsman MJ, Hanekamp M, Wildschut ED, Tibboel D, Mathot RA. Population pharmacokinetics of midazolam and its metabolites during venoarterial extracorporeal membrane oxygenation in neonates. Clin Pharmacokinet (2010) 49(6):407-19. doi:10.2165/11319970-000000000-00000

123. Harthan AA, Buckley KW, Heger ML, Fortuna RS, Mays K. Medication adsorption into contemporary extracorporeal membrane oxygenator circuits. J Pediatr Pharmacol Ther (2014) 19(4):288-95. doi:10.5863/15516776-19.4.288

124. Jacqz-Aigrain E, Daoud P, Burtin P, Maherzi S, Beaufils F. Pharmacokinetics of midazolam during continuous infusion in critically ill neonates. Eur J Clin Pharmacol (1992) 42(3):329-32. doi:10.1007/BF00266357

125. Shekerdemian L, Bush A, Redington A. Cardiovascular effects of intravenous midazolam after open heart surgery. Arch Dis Child (1997) 76(1):57-61. doi:10.1136/adc.76.1.57

126. Bhatt-Meht V, Annich G. Sedative clearance during extracorporeal membrane oxygenation. Perfusion (2005) 20(6):309-15. doi:10.1191/ 0267659105pf827oa

127. Whalen LD, Di Gennaro JL, Irby GA, Yanay O, Zimmerman JJ. Longterm dexmedetomidine use and safety profile among critically ill children and neonates. Pediatr Crit Care Med (2014) 15(8):706-14. doi:10.1097/ PCC. 0000000000000200

128. Wildschut ED, van Saet A, Pokorna P, Ahsman MJ, Van den Anker JN, Tibboel D. The impact of extracorporeal life support and hypothermia on drug disposition in critically ill infants and children. Pediatr Clin North Am (2012) 59(5):1183-204. doi:10.1016/j.pcl.2012.07.013

129. Elliott ES, Buck ML. Phenobarbital dosing and pharmacokinetics in a neonate receiving extracorporeal membrane oxygenation. Ann Pharmacother (1999) 33(4):419-22. doi:10.1345/aph.18248

130. Wildschut ED, Ahsman MJ, Allegaert K, Mathot RA, Tibboel D. Determinants of drug absorption in different ECMO circuits. Intensive Care Med (2010) 36(12):2109-16. doi:10.1007/s00134-010-2041-z

131. Peters JW, Anderson BJ, Simons SH, Uges DR, Tibboel D. Morphine pharmacokinetics during venoarterial extracorporeal membrane oxygenation in neonates. Intensive Care Med (2005) 31(2):257-63. doi:10.1007/ s00134-004-2545-5 
132. Meyer MM, Berens RJ. Efficacy of an enteral 10-day methadone wean to prevent opioid withdrawal in fentanyl-tolerant pediatric intensive care unit patients. Pediatr Crit Care Med (2001) 2(4):329-33. doi:10.1097/00130478200110000-00009

133. Robertson RC, Darsey E, Fortenberry JD, Pettignano R, Hartley G. Evaluation of an opiate-weaning protocol using methadone in pediatric intensive care unit patients. Pediatr Crit Care Med (2000) 1(2):119-23. doi:10.1097/00130478-200010000-00005

134. Yaster M, Kost-Byerly S, Berde C, Billet C. The management of opioid and benzodiazepine dependence in infants, children, and adolescents. Pediatrics (1996) 98(1):135-40.

135. Dominguez KD, Crowley MR, Coleman DM, Katz RW, Wilkins DG, Kelly HW. Withdrawal from lorazepam in critically ill children. Ann Pharmacother (2006) 40(6):1035-9. doi:10.1345/aph.1G701

136. Berkowitz GS, Mehalek KE, Chitkara U, Rosenberg J, Cogswell C, Berkowitz RL. Doppler umbilical velocimetry in the prediction of adverse outcome in pregnancies at risk for intrauterine growth retardation. Obstet Gynecol (1988) 71(5):742-6.

137. Berens RJ, Meyer MT, Mikhailov TA, Colpaert KD, Czarnecki ML, Ghanayem NS, et al. A prospective evaluation of opioid weaning in opioid-dependent pediatric critical care patients. Anesth Analg (2006) 102(4):1045-50. doi:10.1213/01.ane.0000202395.94542.3e

138. Bowens CD, Thompson JA, Thompson MT, Breitzka RL, Thompson DG, Sheeran PW. A trial of methadone tapering schedules in pediatric intensive care unit patients exposed to prolonged sedative infusions. Pediatr Crit Care Med (2011) 12(5):504-11. doi:10.1097/PCC.0b013e3181fe38f5

139. Schieveld JN, Leroy PL, van Os J, Nicolai J, Vos GD, Leentjens AF. Pediatric delirium in critical illness: phenomenology, clinical correlates and treatment response in 40 cases in the pediatric intensive care unit. Intensive Care Med (2007) 33(6):1033-40. doi:10.1007/s00134-007-0637-8

140. Silver G, Traube C, Kearney J, Kelly D, Yoon MJ, Nash Moyal W, et al. Detecting pediatric delirium: development of a rapid observational assessment tool. Intensive Care Med (2012) 38(6):1025-31. doi:10.1007/s00134-012-2518-z

141. Smith HA, Boyd J, Fuchs DC, Melvin K, Berry P, Shintani A, et al. Diagnosing delirium in critically ill children: validity and reliability of the pediatric confusion assessment method for the intensive care unit. Crit Care Med (2011) 39(1):150-7. doi:10.1097/CCM.0b013e3181feb489
142. Madden K, Turkel S, Jacobson J, Epstein D, Moromisato DY. Recurrent delirium after surgery for congenital heart disease in an infant. Pediatr Crit Care Med (2011) 12(6):e413-5. doi:10.1097/PCC.0b013e31820ac2bf

143. Silver GH, Kearney JA, Kutko MC, Bartell AS. Infant delirium in pediatric critical care settings. Am J Psychiatry (2010) 167(10):1172-7. doi:10.1176/ appi.ajp.2010.09111606

144. Traube C, Silver G, Kearney J, Patel A, Atkinson TM, Yoon MJ, et al. Cornell assessment of pediatric delirium: a valid, rapid, observational tool for screening delirium in the PICU*. Crit Care Med (2014) 42(3):656-63. doi:10.1097/ CCM.0b013e3182a66b76

145. van Dijk M, Knoester H, van Beusekom BS, Ista E. Screening pediatric delirium with an adapted version of the Sophia observation withdrawal symptoms scale (SOS). Intensive Care Med (2012) 38(3):531-2. doi:10.1007/ s00134-011-2434-7

146. Slooff VD, Spaans E, van Puijenbroek E, Jessurun N, van Beusekom BS, de Hoog $\mathrm{M}$, et al. Adverse events of haloperidol for the treatment of delirium in critically ill children. Intensive Care Med (2014) 40(10):1602-3. doi:10.1007/s00134-014-3446-x

147. Hanison J, Conway D. A multifaceted approach to prevention of delirium on intensive care. BMJQual Improv Rep (2015) 4(1):u209656.w4000. doi:10.1136/bmjquality.u209656.w4000

Conflict of Interest Statement: The authors declare that the research was conducted in the absence of any commercial or financial relationships that could be construed as a potential conflict of interest.

The reviewer GH and handling editor declared their shared affiliation, and the handling editor states that the process nevertheless met the standards of a fair and objective review.

Copyright (c) 2016 Vet, Kleiber, Ista, de Hoog and de Wildt. This is an open-access article distributed under the terms of the Creative Commons Attribution License (CC $B Y)$. The use, distribution or reproduction in other forums is permitted, provided the original author(s) or licensor are credited and that the original publication in this journal is cited, in accordance with accepted academic practice. No use, distribution or reproduction is permitted which does not comply with these terms. 